\title{
TO THE NEW TORI
}

Oliver L. Austiu, Jr.

Head, Willlife Branch.

NRS-GHQ-SCAP.

The appearance of this number, the first post-war issue of Tori. is significant of the rebirth of ornithology in Japan. The Onithological Society of Japan is to be congratulated for revivifying itself, and so setting this excellent example for other natural history societies to follow. It is fitting that its organ, Tori, should set the highest standards for other Japanese publications in the peaceful sciences to follow.

As the leading ornithological periodical in Japan, Tori has a two-fold mission. First it must stimulate and correlate ornithological activities at home in Japan. Second, it must interpret and make available to the rest of the world the results of these activities. To accomplish these aims, Tori must adopt strong, new editorial policies, based on modern, democratic, scientific practices and strict scientific truth.

Of paramount importance is the quality of the articles it publishes. The highest standards must be set, and articles selected for publication strictly according to those standards. Manuscript must be judgerl on the basis of their individual, intrinsic worth, and not on the standing or reputation of their authors. This should be done preferably by an elitorial board rather than by a single editor. The editors must have no compunction in refusing material not up to their standards, regardless of its source. Quality must not be sacrificed for quantity.

This does not mean the exclusion of all non-technical writing or minor notes, but the proper designation of space according to the importance of the subject matter. The tendency to expand material worth only a few lines or paragraphs into leading articles must be avoided. The creation of a regular department for short, general notes of lesser importance on occurrences, habits and other phenomena would simplify this problem, and be of great value.

Modern bibliographical practices must be adopted to facilitate library filing and referencing to its contents by other workers. Anonymity must be avoided, and definite authorship stated for all articles, notes and comments. Regularity of issue must be striven for, and the regrettable habit of predating issues discontinued. 
Of greatest value to ornithology both in Japan and abroad would be the establishment of a regular review section, to note, summarize and criticize all ther publications on the birds of Japan or of interest to Japanese ornithologists. Honest, constructive criticism is one of the basic tenets of democratic, scientific thought, and is biklly nceded for the improvement of all Japanese science.

Last, while Tori nust be written in Japanese to accomplish its all important mision at home, a summary of each article should be appended in one of the more wirly-read langes of science, Huglish, Fronch, or German. Ocherwise, it can be neither understood wr appreciated abroad.

It is ny eamest hope that the Ornithological Society of Japan and Tori will continie to grow and prosper under the new democratic precepts adopted by Japan, and take their rightful place among the learned societies and scientific periodicals of the world.

Tokyo-November 1947.

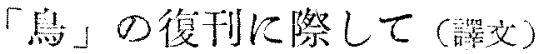

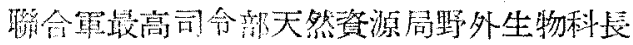 日本鳥罡俞名譽會员 オー・エル・オースチン}

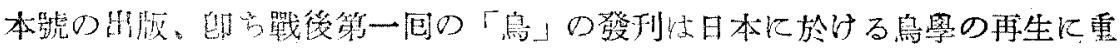

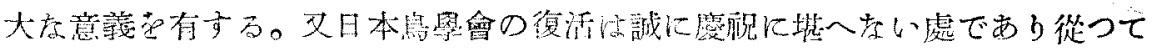

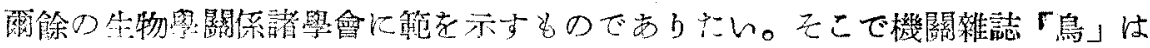

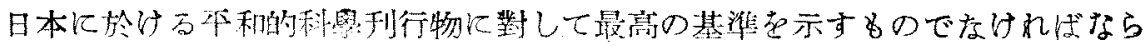
ton。

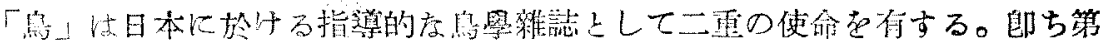

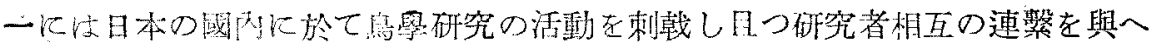

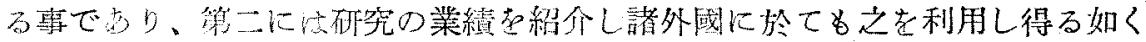

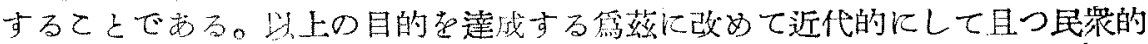

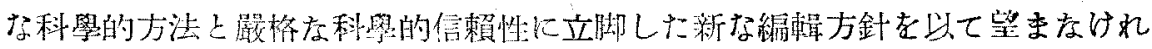
壮度ら双。

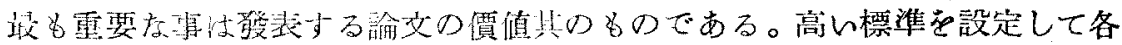

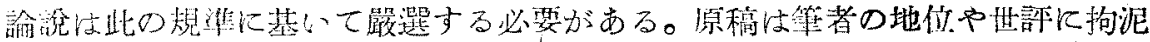

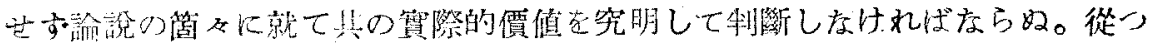

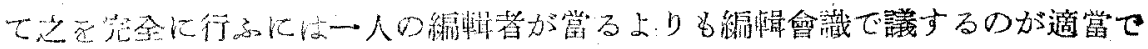

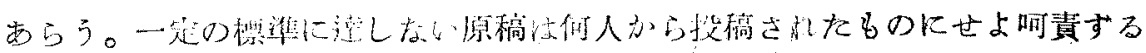




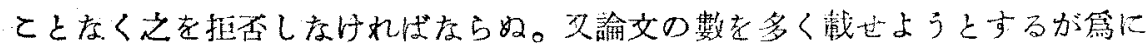
內容のよい長い論文を犠牲にしてはいけない。

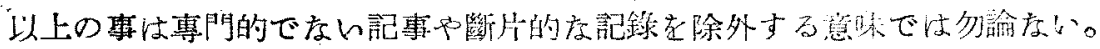

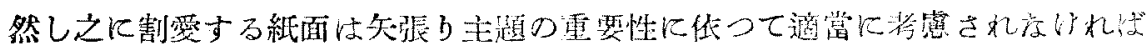

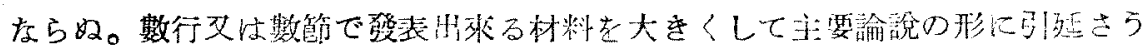
とする樣を傾向々排斥する必要がある。

特别を重要性のない記錄、習性及じ其の他の現到に閣する特別な闌を設ける

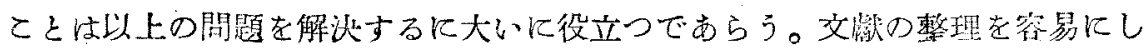
又他の研究者の業績の參照を簡便てする第近代的存參考支獻目錄を附する必要

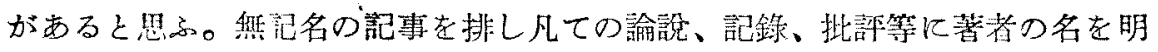

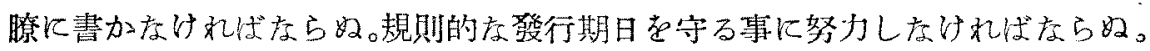

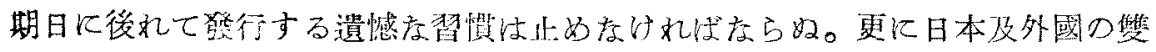

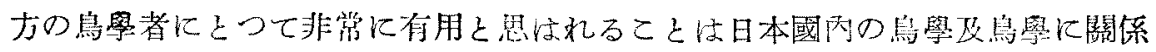

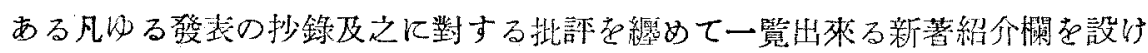
るととである。筫際正直な建設的孝批評は民主的な科學思想の信條で西つて、

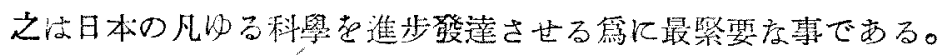

最後に斉望したい事は「鳥」は國內的の必要上から日本售范以て出版される

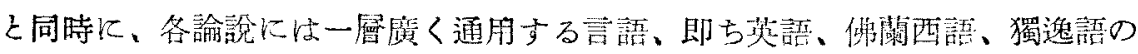
何れかの要約を附錄しなければならない。然らざれば外四に於てはそれを讀ま れる事もなく、页價值を認められることも出來ないからである。

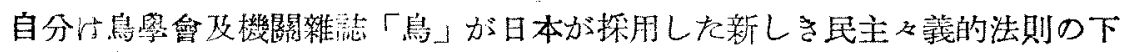
に於て成長續け盛大と店る事を望さ。そして世界各國の學會及び科學雜誌々 伍して正當夸地位を占むるに至らんてとを心より希望し念願するものである。

1947 年 11 月識す

\section{鳥」復刊の箨}

會頭 理學博士 埋 田 長 禮

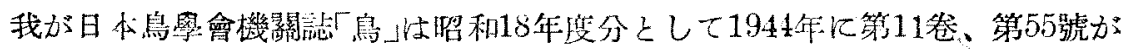

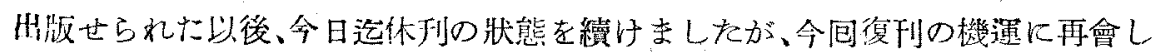

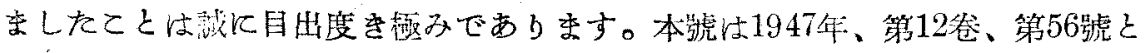
して出版されます故、1945年と1946年分は空くことになります。時師柄 1 回の

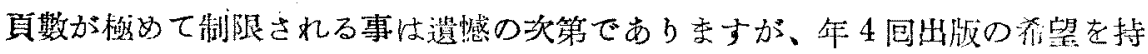

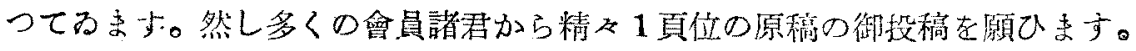

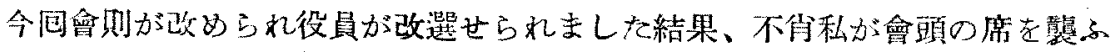

